\title{
Államnyelvi hatás a kárpátaljai magyar felsőoktatásban tanuló diákok nyelvhasználatában*
}

\author{
GAZDAG VILMOS
}

\section{Bevezetés}

A diáknyelv csoportnyelvi jellegéből fakadóan bizonyos mértékben eltér a köznyelvtől, s ez természetesen leginkább a szókészleti sajátosságaiban mutatkozik meg, mely elsősorban a diákélettel kapcsolatos tárgyak, fogalmak megnevezéséhez kötődik (SzÜTS 1994: 52). Ugyanakkor a diáknyelv sem tekinthető teljességgel egységesnek. Különbség mutatkozik az elemi és általános iskolások, a gimnáziumi és líceumi tanulók, valamint a felsőoktatási intézmények hallgatóinak nyelvhasználatában is. BILÁSZ BOGLÁRKA (2011: 29) például elsősorban az általános iskola felső tagozatában tanulókat és a középfokú oktatási intézményeket látogató diákokat tekinti a diáknyelv használóinak, s az egyetemi hallgatók nyelvét már a tágabb kategóriaként értelmezhető ifjúsági nyelvhez sorolja. De különbségek fedezhetők fel akár a földrajzi elhelyezkedés szempontjából is (erröl lásd pl. PARAPATICS 2013). Különösképp igaz lehet ez a határon túli, kétnyelvüségi körülmények között élő diákok nyelvhasználatára.

Bár a diáknyelv nem korlátozódik a szükebb értelemben vett iskolai és kollégiumi szókincsre (ennek okairól lásd pl. HoFFMANN 1996), jelen munka keretein belül én mégis a kárpátaljai magyar felsőoktatási intézményekben tanuló hallgatók nyelvhasználatában jelentkező orosz és ukrán nyelvi sajátosságok ezen szegmensét próbálom meg bemutatni. Kutatásom így alapjában véve a kárpátaljai magyar felsőoktatás regiszterében jelentkező államnyelvi hatást, illetve az oktatás témaköréhez valamilyen módon kapcsolódó kölcsönszavakat vizsgálja.

\section{Mit tudunk a kárpátaljai magyar diáknyelvről?}

A kárpátaljai magyar diáknyelv szókincse GYÖRKE MAGDOLNA szerint két csoportra osztható. Az elsőbe a magyarországi diáknyelvben is elterjedt szavak

* Az Innovációs és Technológiai Minisztérium ÚNKP-20-4 kódszámú Új Nemzeti Kiválóság Programjának a Nemzeti Kutatási, Fejlesztési és Innovációs Alapból finanszírozott szakmai támogatásával készült. 
sorolhatóak (töri, doli, matek, suli), a másodikba pedig az orosz vagy ukrán nyelvből átvett elemek (zacsot 'kollokvium', obsi 'diákotthon', prakitka 'gyakorlat' stb.), melyek csak a kárpátaljai diákság nyelvhasználatára jellemzőek (1991: 7071). BORBÉLY EDIT az Ungvári Nemzeti Egyetemen tanuló kárpátaljai magyar hallgatók körében passzív módszerrel végzett kutatás eredményeinek bemutatása során ugyancsak azt hangsúlyozza, hogy ,a kárpátaljai diákság — mint a lakosság idősebb nemzedékei — nagyon sok kölcsönszót használ" (2004: 14). MÁRKU ANITA kutatása a beregszászi föiskola, illetve az ungvári egyetem hallgatóinak válaszai alapján azt is igazolta, hogy ,a kárpátaljai magyar hallgatók vélekedése szerint a kölcsönzés természetes velejárója a nyelvi kontaktusnak" (2008: 2739). KISS ANITA a Magyarországon tanuló kárpátaljai származású hallgatók körében végzett vizsgálatokat, $\mathrm{s}$ arra a következtetésre jut, hogy az ő nyelvhasználatukban is kimutatható az orosz és ukrán nyelvi hatás (2020: 129-142).

A kárpátaljai magyar iskolai szaknyelvben meghonosodott másodnyelvi elemekkel is foglalkozik jelen írás szerzőjének A nyelvválasztási stratégia és a pályaválasztás összefüggései a kárpátaljai beregszászi járás magyar középiskolásai körében címü tanulmánya, mely azt hangsúlyozza, hogy a másodnyelvi elemek meghonosodása az iskolai szaknyelvben természetes jelenség (GAZDAG 2013a: 216). NAgY NATÁlia a Técsői Magyar Tannyelvü Református Líceum és a Técsői Hollósi Simon Középiskola tanulóinak körében végzett kérdőíves felmérés adatait fogalomkörönként elemzi, külön hangsúlyt fektetve az államnyelvböl kölcsönzött szavak bemutatására (2020). Mivel a munka — ahogyan a kárpátaljai diákok körében végzett más nyelvhasználati és attitüdvizsgálatok (lásd pl. CSERNICSKÓ-BEREGSZÁSZI 1998, BEREGSZÁSZI-MÁRKU 2003, LAKATOS 2011) is nem csak az oktatás tárgykörében megmutatkozó szláv hatás tanulmányozását tüzte ki céljául, a nyelvhasználat más színtereit is érinti.

A vizsgálatok kiterjedtek az ukrán tannyelvű iskolában tanulók nyelvhasználatra is, s azt igazolták, hogy a szaknyelvek terminológiáját a megkérdezettek általában csak azon a nyelven (esetünkben ukránul) ismerik, amelyen elsajátították azt (pl. GYÖRKE 1991: 66-69). Ez alapján azt feltételezhetnénk, hogy az ukrán iskolába járó magyar anyanyelvü tanulók is hasonló helyzetben vannak, amikor az iskolai dolgaikról kérdezik őket. A tapasztalatok azonban azt mutatják, hogy mivel a kisiskolások naponta kommunikálnak magyar iskolában tanuló barátaikkal is, így mindkét nyelven megismerik az iskolai nyelvhasználat sajátos terminológiáját (GAZDAG 2011: 357, 2012: 83-87).

\section{A kutatásról}

A kutatás során a kárpátaljai felsőoktatási intézményekben tanuló magyar anyanyelvü diákok nyelvhasználatát vizsgáltam, kiemelt hangsúlyt fektetve a kétnyelvüség nyomán jelentkező kontaktusjelenségek tanulmányozására. A világjárvány 
sajnálatos módon jelentős mértékben befolyásolta a kutatás kivitelezésének lehetőségeit is, ezért a személyes megkeresések helyett a kérdőíves felmérést a virtuális térben kényszerültem elvégezni. A Facebookon közzétett kérdőív elsősorban az ismerőseimhez, illetve az általuk történő újramegosztások révén az ő ismerőseikhez jutott el. Így kutatásom az oktatási intézmények, illetve a diáklétszámok tekintetében sem tekinthető reprezentatívnak. Ugyanakkor úgy vélem, hogy ettől függetlenül vizsgálatom mégis értékes eredményeket hozhat. A kérdőív a szociolingvisztikai, a dialektológiai és a kontaktusnyelvészeti kutatások során alkalmazott kérdéstípusokat tartalmazott. A közel egy hónapon át folyó online felmérés eredményeként 167 kérdőívet tudtam feldolgozni.

\subsection{Az adatközlökről}

Mivel az adatközlők túlnyomó többsége a pedagógusképzésben tanul, így a nemek aránya jól tükrözi az e téren továbbtanuló kárpátaljai diákok megoszlását is. A kérdőívet összesen 141 nő és 26 férfi töltötte ki.

Földrajzi tekintetben Kárpátalja magyarlakta vidékét teljességgel lefedik az adatközlők. 162 fő állandó jelleggel Kárpátalján él, további 5 fö jelölt meg valamilyen külföldi lakhelyet. Az adatok 68 településről valók (az adatközlők járásonkénti ${ }^{1}$ eloszlását lásd az 1 . táblázatban).

\begin{tabular}{|l|c|c|}
\hline \multicolumn{1}{|c|}{ Járás } & Település száma & Adatközlö (fö) \\
\hline Beregszászi járás & 44 & 116 \\
\hline Huszti járás & 2 & 3 \\
\hline Munkácsi járás & 3 & 4 \\
\hline Técsői Járás & 2 & 6 \\
\hline Ungvári járás & 14 & 33 \\
\hline Külföld & 3 & 5 \\
\hline
\end{tabular}

1. táblázat. Az adatközlők lakhelye járásonkénti bontásban

\subsection{A képzési adatokról}

Akadtak olyan adatközlők is — összesen öt fö - , akik nem feleltek meg az általam elözetesen kijelölt célcsoportnak, vagyis nem kárpátaljai intézményben ${ }^{2}$ vagy nem felsőoktatási intézményben ${ }^{3}$ folytatják tanulmányaikat. Mivel azonban az ő nyelvhasználatuk is tükrözhet másodnyelvi sajátosságokat, az elemzés során a tőlük beérkezett válaszokat is figyelembe vettem. Kárpátaljáról az alábbi három oktatási intézmény hallgatóitól kaptam válaszokat: II. Rákóczi Ferenc Kárpátaljai

\footnotetext{
${ }^{1}$ A települések járásokba történő sorolása Kárpátalja új közigazgatási felosztásának megfelelően történt.

${ }^{2}$ Debreceni Egyetem, Eötvös Loránd Tudományegyetem, Nemzeti Közszolgálati Egyetem, Nyíregyházi Egyetem.

${ }^{3}$ Mezőkaszonyi Arany János Líceum.
} 
Magyar Főiskola (RF KMF): 98 fő; a II. Rákóczi Ferenc Kárpátaljai Magyar Főiskola Szakgimnáziuma (KMF FSZI): 40 fö, Ungvári Nemzeti Egyetem (UNE): 23 fö; egy adatközlő nem jelölte meg az általa látogatott intézményt.

Ehhez kapcsolódóan fontos lehet megjegyezni azt is, hogy bár a „magyar nyelvü oktatásnak nagy hagyományai vannak a mai Kárpátalja területén”, de „minél magasabb oktatási szintről van szó, annál több magyar gyerek és fiatal tanul az állam hivatalos nyelvén" (CSERNICSKÓ és mtsai 2020: 13). Így például csak 2 felsőoktatási intézményben 7 szakon képeznek magyar nyelven pedagógusokat, s ugyanennyi azoknak a nem pedagógiai szakoknak a száma is, ahol magyar nyelvü képzés folyik.

A kérdőívet kitöltő hallgatók közül 145 fő magyar (közülük 16 fö kétszakos), 10 fö ukrán, 8 fő angol, 2 fő román alapnyelvü képzésben vesz részt, 1 fö az orosz nyelvet jelölte meg a képzés alapnyelveként, illetve további 1 fó nem adott választ erre a kérdésre (részletesen lásd a 2. táblázatban). A 167 hallgató közül 145 jár nappali tagozatos képzésbe, 22 pedig levelezö tagozaton folytatja tanulmányait.

\begin{tabular}{|c|c|c|c|}
\hline Képzés nyelve & Szak & Fö & Hallgató \\
\hline \multirow{12}{*}{ magyar } & óvodapedagógia & 41 & \multirow{12}{*}{145} \\
\hline & óvodapedagógia & 15 & \\
\hline & szociális munkás & 13 & \\
\hline & számvitel és adóügy & 11 & \\
\hline & tanítói & 10 & \\
\hline & matematika és informatika & 5 & \\
\hline & nemzetközi kapcsolatok & 4 & \\
\hline & turizmus & 4 & \\
\hline & történelem & 3 & \\
\hline & biológia & 3 & \\
\hline & földrajz & 1 & \\
\hline & két szakos képzés & 16 & \\
\hline \multirow{5}{*}{ ukrán } & ukrán nyelv és irodalom & 4 & \multirow{5}{*}{10} \\
\hline & számvitel és adóügy & 2 & \\
\hline & orvosi & 2 & \\
\hline & testnevelöi & 1 & \\
\hline & fizika Phd & 1 & \\
\hline angol & angol nyelv és irodalom & 8 & 8 \\
\hline egyéb & román nyelv és irodalom & 2 & 2 \\
\hline orosz & szlavisztika & 1 & 1 \\
\hline
\end{tabular}

2. táblázat. A képzés alapnyelve 
Amint az a fenti táblázatból is kitünik, vannak olyan képzések, amelyek több intézményben is tanulhatók, bár az óvodapedagógusok képzése két külön képzési szinten, lényegében egymásra épülve folyik. A számvitel és adóügy szakos képzés alapnyelvét a hallgatók nem egyféleképpen bírálták el. A magyar nyelvü képzést — nyilván az ukrán nyelven tanult szaktárgyak miatt — két hallgató ugyanis ukrán alapnyelvüként jelölte meg.

\subsection{Az adatközlők nyelvismeretéről és nyelvhasználatáról}

A 167 válaszadó közül 159 fö a magyart, 5 fö az ukránt tekinti anyanyelvének, illetve további 3 fö több nyelvet is anyanyelveként jelölt meg (magyar, ukrán, orosz, román).

A kárpátaljai diákok továbbtanulását illetően a szak-, illetve pályaválasztást nem csupán az érdeklődési kör határozza meg, hanem a nyelvtudás, valamint az egyes szakok képzési nyelve is (erről lásd pl. GAZDAG 2013a). Ezért értelemszerüen szükséges az adatközlők nyelvtudását és nyelvhasználati szokásait is felmérni.

A válaszadók magyar nyelvi kompetenciái igen magasak. A 159 magyar anyanyelvü válaszadón túl 7 fő mondta azt, hogy jól ismeri a magyar nyelvet. Az 5 ukrán anyanyelvü adatközlő mellett 21 fö tekinti az ukrán nyelvtudását anyanyelvi szintünek, 64 fö a jól ismerem, 66 fö a kicsit ismerem, 11 fö pedig az alig ismerem lehetőséget választotta. Az eredmények igazolják az ukrán nyelv oktatási módszereinek a sikertelenségét is, ugyanis a kárpátaljai magyar tanulók az első osztálytól kezdődően kötelező jelleggel tanulják az államnyelvet (BEREGSZÁSZICSERNICSKÓ 2017).

Az angol nyelv ismeretére vonatkozó adatok, azt mutatják, hogy ennek az ismereti szintje magasabb, mint az államnyelvé (ennek okairól lásd: CSERNICSKÓ 2015, HUSZTI 2017, MÁTÉ 2017). A megkérdezettek az angol és/vagy német nyelv ismeretére vonatkozóan ugyanis az alábbi válaszokat adták: 5 fö anyanyelvi szinten, 77 fő jól, 73 kicsit, 11 fö alig ismeri az adott nyelvet.

Lényegesen alacsonyabb az orosz nyelv ismereti szintje, ami nyilvánvalóan azzal is összefüggésben áll, hogy az orosz nyelvet már nem oktatják a kárpátaljai magyar tannyelvü iskolákban. Anyanyelvi szinten csupán 15 fö ismeri. 23 fö jól ismeri, 57 fö kicsit ismeri, 39 fö alig ismeri, 25 fö egyáltalán nem ismeri, 8 fö pedig nem válaszolt.

A nyelvek ismereti szintjére, amint arról fentebb már szót is ejtettem, komoly hatást gyakorol az oktatás is, ezért megkérdeztem az adatközlőink korábbi iskoláinak tannyelvét is. E téren is a magyar tannyelv túlsúlya a jellemző.

Az elemi iskolai tanulmányait 121 fö magyarul, 39 fö ukránul végezte, illetve 7 fó nem adott meg semmilyen tannyelvet. Az általános iskolában 134 fó magyarul, 30 fö ukránul tanult, és 3 fő nem válaszolt. A középiskolai osztályokban 142 fó magyar, 11 fö ukrán, 1 fó orosz nyelvü képzésben részesült, illetve 13 fö nem válaszolt. 
Az adatokat összevetve megfigyelhető az, hogy a képzés előrehaladtával a tanulmányaikat ukrán nyelven kezdő diákok egy része átkerült a magyar tannyelvü képzésbe, ami vagy a továbbtanulás tudatos tervezésének, vagy esetleg az ukrán tannyelven való tanulás nehézségeinek a következménye lehet (az ukrán iskolába íratott magyar gyermekek nehézségeiről lásd pl. CSERNICSKÓ-GÖNCZ 2009, SÉRA 2009). A magyar anyanyelvű gyermekek orosz tannyelven való oktatása napjainkban már Kárpátalján sem jellemző. Az elemi és általános iskolai tanulmányait magyarul, de a középiskolai osztályokat már orosz nyelven végzett egy adatközlő nem is helyben, hanem Oroszországban tanult az érintett időszakban.

Az adatközlök többsége az egyes kommunikációs színtereken is a magyar nyelvet használja. Alig vannak olyanok, akik az ukrán vagy orosz nyelvet is használnák az informális, családon belüli kommunikációban. A formálisabb nyelvhasználat irányába haladva (pl. a tanárokkal történő kommunikációban), a többnyelvü környezet követelményeként valamelyest nő az ukrán nyelv használati aránya. Az orosz és más nyelvek viszont egyáltalán nem használatosak.

A különféle tevékenységekhez füződő nyelvhasználat vizsgálata kapcsán kitünik, hogy az írás, olvasás, számolás és tévénézés jórészt magyar nyelven történik, viszont a zenehallgatás és internetezés során már sokkal alacsonyabb mértékben használatos a magyar nyelv. A két utóbbi tevékenység végzésekor a válaszadók jelentős hányada egyidejüleg több nyelvet is használni szokott. Az iskolai oktatástól való teljes körü elkülönítésre utal az, hogy írni, olvasni és számolni is csak 2-3 fó szokott ukrán nyelven.

\section{A diákok nyelvhasználatában jelentkezö államnyelvi hatás}

Az adatközlők fent ismertetett nyelvismereti mutatói és nyelvi helyzete egyértelmủen magyar dominanciáról tanúskodnak. Ugyanakkor a korábbi, nem iskoláskorú adatközlők körében végzett felmérések eredményei (lásd pl. GAZDAG 2010, 2017), illetve az ismertetett idevágó kutatások alapján az feltételezhetö, hogy a szükebb értelemben vett iskolai nyelvhasználatban ettöl függetlenül is megjelennek a másodnyelvi hatás következtében elsajátított kölcsönszavak.

4.1. Egy korábbi, az ukrán iskolákban tanuló magyar anyanyelvü diákok nyelvhasználatát vizsgáló kutatás (lásd GAZDAG 2013b) eredményei azt igazolták, hogy a tanulók nyelvhasználatában előforduló ukrán lexikai elemek föként a tantárgyak, illetve az iskolai egységek megnevezései közül kerülnek ki. Ebböl kiindulva az adatközlőket két felsorolás elkészítésére kértem.

Egyrészt azokat a tantárgyakat kellett felsorolniuk, amelyeket a képzésük során tanulnak/tanultak. A beérkezett válaszok nem tartalmaztak ukrán nyelvi kölcsönzéseket. Az egyik óvodapedagógia szakos hallgató a matematika tárgy érettségi előkészítőjét matematika $(Z N O)$ formában nevezte meg. A ZNO (< ukrán betüszó зовнішне незалежне оиінювання 'külső független tesztelés') a 
kárpátaljai magyarok körében zeneó ejtési formában aktív használatú lexikális elem. További két hallgató az általa tanult tantárgyakat ukrán nyelven, cirill betüs írásmóddal adta meg: közülük az egyik ukrán szakos, a másik pedig magyar nyelv és irodalom szakos ukrán anyanyelvü hallgató.

A másik feladat a tanulmányaikhoz szükséges $\mathrm{s}$ a táskájukban jellemzően megtalálható eszközök felsorolására vonatkozott. A legtöbb adatközlő itt csupán az alábbi eszközöket sorolta fel: toll, tolltartó, füzet, napló, könyvek, számológép, hibajavitó, szövegkiemelő. Ez azzal is összefüggésben állhat, hogy a felsőoktatásban a hallgatóknak sokkal kevesebb tanszerre van szükségük, mint például egy általános iskolai tanulónak. Ugyanakkor közöttük is vannak olyanok, akik több füzetet is magukkal visznek az óráikra, s ezeket mappá-ban tartják. Bár ezt az eszközt csupán 3 hallgató említette, közülük kettő a szláv nyelvi átvételként meghonosodott pápka (< ukr., or. папка) megnevezést használta (ettől eltérő használati mértékre utalnak képazonosítási feladat eredményei). Technikai eszközök gyakran szerepelnek a felsőoktatásban: a föiskolai és egyetemi hallgatók túlnyomó többsége rendszeresen magánál tart például valamilyen digitális adathordozót is. Adatközlőink ezt az eszközt igen sokrétüen nevezték meg: 4 hallgató a pendrive, 1 hallgató a flash angol nyelvi alakokat adta meg, 2 hallgató az adathordozó, illetve USB magyar nyelvi változatot, míg 2 hallgató az ukrán kölcsönszóként meghonosodott fless és fleska ( $<\mathrm{ukr}$. флешка, or. флэшка) alakváltozatokat.

4.2. Mivel a korábbi kutatások során az oktatási intézmények bizonyos részlegei, illetve az oktatáshoz kapcsolódó különböző fogalmak kapcsán is sikerült kölcsönszavakat adatolni, ezekre is rákérdeztem kérdöívben. Egy összevont Hogy nevezik? kérdéscsoportban összesen 15 körülírást kellett a válaszadóknak meghatározniuk. A kapott válaszok között rendre megtalálhatók az államnyelvi kölcsönszavak is, sőt ezek az átadó nyelvi, cirill betűs alakváltozatban, illetve magyarosított formában is gyakran előfordultak. Az alábbiakban a kérdésekre adott válaszok közül — dolgozatom témájának megfelelöen — csak a kölcsönszói változatokat, valamint azok számadatait mutatom be:

1. az az egység, amelyhez a szakotok tartozik: fak 'egyetemi kar' < ukr., or. фaк $\leftarrow$ факультет (1 fö); medfak 'egészségügyi kar' < медфак $\leftarrow$ ukr. медичний факультет, оr. медицинский факультет (1 fö); univer 'egyetem' < ukr. університет; оr. университет (1 fö); кафедра 'tanszék' < ukr., or. кафедра (1 fö).

2. az órák megtartására szolgáló helyiségek: auditórium, ${ }^{4}$ illetve ukr. aydumopiя 'előadó terem' (4 fö); kabinet 'szertár, dolgozószoba' < ukr. кабінет; or. кабинет (2 fó).

${ }^{4}$ A szó ismert a magyarországi beszélők körében is, viszont a használatot illetően gyakorisági eltérés figyelhető meg, ugyanis a másodnyelvi hatás miatt Kárpátalján ez mindennapi használatú. 
3. azok a helyiségek, ahol általában a tanárokat kereshetitek: kafedra, illetve ukr., or. кафедра tanszék' (3 fö); dekánát 'dékáni hivatal' < ukr., or. деканат (1 fö); kabinet 'szertár, dolgozószoba' < ukr. кабінет, or. кабинет (1 fó).

4. az a hely, ahol a tanítási időben étkezni szoktatok: jidálnyá, illetve ukr. їальня 'étkezö, étkezde' (2 fö); sztolova 'ebédlö, étkezde' < or. столовая (1 fö).

5. a fél- és tanévek végén előforduló elszámolási időszak: szeszió, szesszió, illetve ukr. сесія 'vizsgaidőszak' (5 fö); praktika 'szakmai gyakorlat' < ukr., or. практика (1 fö); ukr. модульнй контроль 'modulellenörzés' (1 fö).

6. az egyes tantárgyakból készített 3-5 oldal terjedelmü dolgozat: referát, illetve ukr., or. peфepam 'referátum' (4 fö); zálik 'gyakorlati jegy' < ukr. залік (1 fö); ukr. презентаиія 'prezentáció, előadás' (1 fö).

7. a tanórák keretében írt összefoglaló jellegü dolgozatok: referát 'referátum, beszámoló' < ukr., or. peферат (1 fö).

8. a testnevelés órák megtartására szolgáló terem: sportkomplex 'sportcentrum' $<$ ukr., or. спорткомплекс $\leftarrow$ спортивний комплекс (1 fö).

9. az ünnepi és más nagyobb szabású rendezvények megtartására szolgáló terem: ukr. актовий зал 'dísz- v. bálterem' (1 fö); a rektorát épület diszterme, rektorát 'rektori hivatal' < ukr., or. peкторат (1 fö).

10. a vizsga- és beszámoló jegyek rögzítésére szolgáló könyvecske: zalikova, zálikova, zalikovka, zálikovka, zályikovka, záliková knézská, zályikavká knézská, illetve ukr. залікова, заліковка, залікова книжкка 'leckekönyv, index' (22 fö).

11. a tanári magyarázat füzetben történő írásbeli rögzítése: konszpekt, konspektus 'jegyzet, összefoglaló' < ukr., or. конспекm, az utóbbi nyilván a latinos hangzáshoz igazodó hiperkorrekt alak (1fö); ukr., or. диктовка diktálás utáni jegyzetelés (1 fö).

12. a tanulmányi eredmény alapján havonta folyósított pénzbeli juttatás: sztipi, sztipendium, sztippendium, sztyipi, stipendium, illetve стипендія 'ösztöndíj' < ukr. стипендія, оr. стипендия (111)

13. a pótvizsga, kreditátvitel vagy szabadóra látogatás kapcsán írt dokumentum: akademka 'tanévhalasztás' < or. академка (1 fö); zajava, zájáva, zájava 'kérelem' < ukr. заява (3 fö); dovidka 'igazolás, jelentés' < ukr. довідка (2 fö); perezdácsa 'vizsga/kollokvium megismétlése, pótvizsga' < ukr. перездача, or. пересдача (1 fö).

14. a kollégium bejáratánál szolgálatot teljesítő személy: ohorona 'ör, biztonsági ör' < ukr. охорона (1 fö); ohrányik 'biztonsági ör' < or. охранник (1 fö).

15. az egy tanév alatt, adott téma kapcsán írt tudományos dolgozat: kurszova, kurszová, illetve курсова 'évfolyammunka' < ukr. курсова робота, or. курсовая работа (4 fö).

Amint az a fentiekből kitünik, mindegyik kérdésre érkeztek kölcsönszói válaszok. Ezek gyakorisága ugyanakkor igencsak eltérő. A legtöbb szó kapcsán csak 1-2 említés adatolható, de vannak olyan kölcsönszavak is (ilyen például a sztipi 
és a hozzá kapcsolódó alakváltozatok), amelyek magas előfordulási arányban jelentek meg a válaszokban.

A kérdésekre adott kölcsönszói válaszok számos más nyelvi jelenség megfigyelését is lehetővé teszik. Jól tükrözik például azt, hogy az egyes szavak meghonosodása során az átvevő nyelvben milyen sokrétüen alakulhat a szó alakja (lásd pl. a zalikova és zajava szavak alakváltozatait) (GAZDAG 2018).

A szavak jelentős részének azonos a hangalakja az orosz és ukrán nyelvben, így az ilyen esetekben az átadó nyelv meghatározása a kulturális, történelmi és gazdasági szempontok figyelembevétele mellett lehetséges. Természetesen vannak olyan átvételek is, amelyek a két nyelvben eltérő hangalakkal rendelkeznek, s így könnyedén azonosíthatóvá teszik az átadó nyelvet (pl. a dovidka szó esetében az orosz nyelvi megfelelö a справка lenne), és olyanok is elöfordulnak, amelyek párhuzamos kölcsönzésként kerültek a magyar nyelvbe: ilyen például az ohorona ohrányik, jidálnyá sztolova szópár.

A szakokkal kapcsolatosan ugyancsak a magyar nyelvi megnevezések dominálnak a megkérdezett hallgatók körében: angolosok, bioszosok, ovpedesek vagy ovisok, számvitelesek, törisek, matekesek stb. Csupán egyetlen hallgató említette a gyógyszerész hallgatók kapcsán a szláv nyelvi eredetü farmacevtek (< ukr., or. фармацевт 'gyógyszerész') megnevezést.

Mivel a korábbi kutatások a diákok szálláshelyét jelölő fogalomkörben rendre kimutatták az orosz nyelvi hatást, ezt ellenőrizendő én is rákérdeztem arra, hogy adatközlöim hol laknak a tanulmányi idejükben. A kérdésre kapott válaszok azonban csak magyar nyelvi megnevezéseket tartalmaznak: kollégiumban, koliban, lakásban, albérletben, otthon. Ez alapján úgy tünik, hogy az orosz eredetü obsi (< or. общежитие) az általam megkérdezett hallgatók körében már nem tekinthető aktív használatú szónak, ami természetesen nem jelenti azt, hogy direkt rákérdezés során esetleg ne tudnák azonosítani azt.

4.3. A fenti fogalommeghatározásokhoz hasonlóan a magyar és kölcsönszói változatok használati mértékét kívántam vizsgálni a képazonosítási feladattal, ahol az adatközlöknek négy tárgyképet kellett felismerniük.

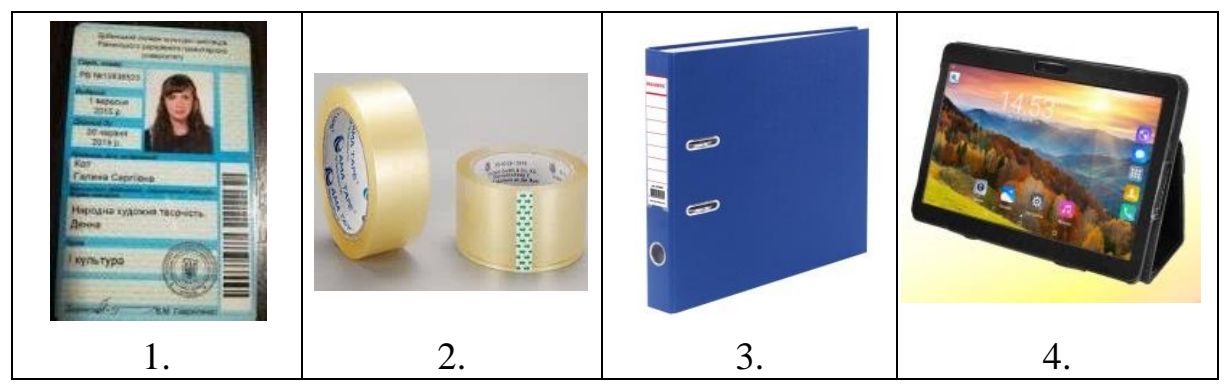

1. ábra. Az azonosításhoz megadott képek 
A képek azonosítása során ismételten a magyar nyelvi elemek túlsúlyát figyelhetjük meg, viszont a kölcsönszói alakok jelenléte is erősen megmutatkozik.

Az első képen látható diákigazolvány kapcsán 20 válaszadó adta meg a sztudi, sztudentka, sztudentszka, sztudentszkij, sztudentszkij kvitok, sztudentszkéj (< ukr. студентський квиток), illetve a személyi igazolvánnyal való nagyfokú hasonlóság okán a paszport (< ukr., or. nacnopm) kölcsönszókat, valamint 12 fö a magyar nyelvi alakokkal párhuzamosan említette ezeket. A második képet 48 válaszadó a szláv kölcsönszói szkocs, szkoccs (< ukr. скотч, or. скотч) szóval azonosította, további 18 fö pedig a magyar nyelvi ragasztószalag, cellux megfelelőkkel párhuzamosan említette ezeket. A harmadik képen látható iratrendező mappát 46 válaszadó pápka-ként (< ukr., or. папка) azonosította (jelentős különbség a tanszerek felsorolásakor adatolt három említéshez képest), illetve 12 fó adta meg vele együtt a magyar nyelvi megfelelöket is. A negyedik képen látható eszközt 9 válaszadó a planset (< ukr., or. планшет) névvel illette, míg további 7 fö a tablett, táblagép magyar nyelvi megfelelőkkel párhuzamosan.

4.4. A tanárok megszólítása kapcsán CSERNICSKÓ ISTVÁN és BEREGSZÁSZI ANIKÓ (1998) kutatása rávilágított arra, hogy az ungvári egyetemen a magyar szakos diákok körében a keresztnév + bácsi/néni, illetve a keresztnév + apai név formák voltak elterjedtebbek, szemben a Magyarországon használatos Tanár úr/Tanárnő formákkal. Az általam közreadott kérdőív e témára vonatkozó részéből kitünik, hogy a válaszadók túlnyomó többsége (122 adatközlö) a Tanár úr/Tanárnö vagy esetleg a tanár néni formákat alkalmazza (utóbbi elsősorban az alsóbb évfolyamokon tanulókra jellemző, akik ezeket a megszólítási formákat az általános és középiskolai tanulmányaikból hozták magukkal), esetenként az adott tanár vezeték- vagy keresztnevével kiegészítve: pl. Alexandra tanárnö, Gabriella tanárnö, Gogola tanár úr. De akadtak olyanok is, akik a keresztnév + néni/bácsi használatát is megemlítették, pl. Erika néni, Gabi néni. Az ukránt vagy ukránul tanító tanárokat a szláv hagyományoknak megfelelően a magyar hallgatók is a keresztnév + apai név formákkal szólítják meg, s ezeket a válaszokat rendre cirill betűs írásmóddal adták meg, pl. Тетяна Іванівна, Наталя Гаврилівна, Олександр Анатолійович.

A hallgatók tulajdonságainak megjelölésében is csupán néhány szláv kölcsönszót sikerült adatolnom. Ezek a következők: tupoj 'butácska' < or. mynoü; illetve a cirill betüs írásmóddal megadott прогульщик 'lógós, munkakerülő'; всезнайка 'mindent tudó'; професорка 'okos, professzor'. Ezen túl egy hallgató ide sorolta a csoportvezetö szerepkörre utaló sztároszta $(<\mathrm{ukr}$., or. cmapocma) megnevezést is.

A fentieken túl arra is kíváncsiak voltam, hogy mennyire tudatos az adatközlök körében a kölcsönszavak használata. Ezért arra is megkértem öket, hogy soroljanak fel olyan szavakat (amennyiben vannak ilyenek), amelyeket ők használnak, de a magyarországi diáktársaik nem. A kapott válaszok között a 
következő kölcsönszavak kerültek elő. Az oktatási szféra kapcsán a korábban már érintett dekanát, dovidka, kafedra, konszpekt, medfák, ohorona, pápka, perezdácsa, sztipi, szkocs, sztároszta, sztolova, sztudentszka, sztudi, zájáva, zálik, záliková szavakat említették, illetve ugyancsak e témakörhöz kapcsolódónak kell tekinteni az alábbi kölcsönszavakat: kursz 'évfolyam' (< ukr., or. кypc), perepusztka 'átengedés, újraírási lehetőség' (< ukr. nерепycmкa), zsurnál 'napló' (< ukr., or. журнал), szkrepki 'gémkapocs' (< or. скрепки), szprávka 'igazolás' (< or. справка), zál 'terem' (< ukr., or. зал).

\section{5. Összefoglalás}

Kutatásom eredményei igazolták, hogy a kárpátaljai magyar felsőoktatásban tanuló hallgatók nyelvhasználatában a magyar nyelv dominanciája, illetve az államnyelv alacsony ismereti szintje mellett is kimutathatók az ukrán és orosz nyelvi hatások. Ezek alapján egyértelműen megállapítható a magyarországi és a kárpátaljai magyar felsőoktatási intézményekben tanuló hallgatók nyelvhasználatának elkülönülése, amely leginkább a kölcsönszavak alkalmazásában mutatkozik meg, de a névhasználatban és a megszólítási formákban is jelen van. Ez utóbbi kapcsán fontos azt is megjegyezni, hogy a korábbi kutatásokhoz képest e téren a diákok jelentős mértékben igazodtak a magyarországi normákhoz.

\section{Irodalom}

BEREGSZÁSZI ANIKÓ-CSERNICSKÓ ISTVÁN 2017. Kidobott pénz vagy megtérülö befektetés? Az ukrán nyelv oktatása Kárpátalja magyar iskoláiban. Magyar Nyelvőr 141: 292-309.

BEREGSZÁSZI ANIKÓ-MÁRKU ANITA 2003. A kárpátaljai magyar középiskolások nyelvhasználatáról. In: CSERNICSKÓ IsTVÁN szerk., A mi szavunk járása. Bevezetés a kárpátaljai magyar nyelvhasználatba. Beregszász, Kárpátaljai Magyar Tanárképző Föiskola. 179-207.

BILÁSZ BOGLÁRKA 2011. Magyar diáknyelv határon innen és túl. Szakdolgozat. Kézirat. Pozsony, Comenius Egyetem, Bölcsészettudományi Kar. URL: http://mnytud.arts. klte.hu/szleng/tanulmanyok/bilas_boglarka2011.pdf (2021. 01. 04.)

BORBÉLY EDIT 2004. Orosz-ukrán elemek a kárpátaljai magyar diákifjúság nyelvhasználatában. Acta Hungarica 15: 14-17.

CSERNICSKÓ ISTVÁN 2015. A kárpátaljai magyar nyelvü oktatás színvonaláról. In: MÁRKU ANITA-HIRES-LÁSZLÓ KORNÉLIA szerk., Nyelvoktatás, kétnyelvüség, nyelvi tájkép. Tanulmányok a Hodinka Antal Nyelvészeti Kutatóközpont kutatásaiból. Ungvár, Autdor-Shark. 13-26.

CSERNICSKÓ ISTVÁN-BEREGSZÁSZI ANIKÓ 1998. A megszólítás változatai az Ungvári Állami Egyetem magyar szakos hallgatóinak körében. In: SÁNDOR KLÁRA szerk., Nyelvi változó - nyelvi változás. A 9. Élönyelvi Konferencia. Szeged, JGYTF Kiadó. 171-178. 
CSERNICSKÓ ISTVÁN-GÖNCZ LAJOS 2009. Tannyelvválasztás a kisebbségi régiókban: Útmutató kárpátaljai magyar szülöknek és pedagógusoknak. Budapest, Magyar Köztársaság Miniszterelnöki Hivatala.

CSERNICSKÓ ISTVÁN-HIRES-LÁSZlÓ KoRnÉliA-KARMACSI ZOLTÁN-MÁRKU ANITAMÁTÉ RÉKA-TÓTH-OROSZ ENIKÖ 2020. Kárpátalja 1920-2020. A kárpátaljai magyarság elmúlt 100 éve. Beregszász, Hodinka Antal Nyelvészeti Kutatóközpont.

GAZDAG VILMOS 2010. Szláv eredetű lexikai elemek a Beregszászi járás magyar nyelvjárásaiban (Kárpátalja, Ukrajna). In: FÁBRI ISTVÁN-KÖTÉL EMÖKE szerk., Határhelyzetek 3. Önmeghatározási kísérletek: hagyományőrzéstöl a nyelvi identitásig. Budapest, Balassi Intézet Márton Áron Szakkollégium. 124-160.

GAZDAG VILMOS 2011. Az ukrán tannyelvü iskolák magyar tanulóinak nyelvhasználata, különös tekintettel a keleti szláv kölcsönszavak fokozott használatára. In. HIRESLÁSZLÓ KORNÉLIA-KARMACSI ZOLTÁN-MÁRKU ANITA szerk., Nyelvi mítoszok, ideológiák, nyelvpolitika és nyelvi emberi jogok Közép-Európában elméletben és gyakorlatban. A 16. Élönyelvi Konferencia elöadásai. Budapest-Beregszász, Tinta KönyvkiadóII. Rákóczi Ferenc Kárpátaljai Magyar Főiskola.

GAZDAG VILMOS 2012. A Beregszászi Járás ukrán tannyelvü iskoláiban tanuló magyar diákok nyelvhasználati sajátosságai. Hungaro-Ruthenica 6: 77-91.

GAZDAG VILMOS 2013a. A nyelvválasztási stratégia és a pályaválasztás összefüggései a kárpátaljai beregszászi járás magyar középiskolásai körében. In: SzOTÁK SzILVIA szerk., Határhelyzetek 5. Sztereotipiák, választások, túlélési stratégiák kisebbségi léthelyzetekben. Budapest, Balassi Intézet Márton Áron Szakkollégium. 200-230.

GAZDAG VILMOS 2013b. Az anyanyelv használati körének módosulásai Kárpátalján. In: KöTÉL EMÖKE-SzOTÁK SZILVIA szerk., Határhelyzetek 4. Hagyomány és jövökép. Anyanyelv(ek), oktatáspolitikai stratégiák, karrierkövetés. Budapest, Balassi Intézet Márton Áron Szakkollégium. 94-120.

GAZDAG VILMOS 2017. Szláv elemek a kárpátaljai Beregszászi járás magyar nyelvjárásaiban. Doktori értekezés. Kézirat. Budapest, Eötvös Loránd Tudományegyetem, Bölcsészettudományi Kar. URL: https://edit.elte.hu/xmlui/handle/10831/40481 (2021. 01.04).

GAZDAG VILMOS 2018. A kárpátaljai magyar nyelvjárásokban meghonosodott keleti szláv kölcsönszavak alakváltozatainak létrejöttéröl. Hungaro-Ruthenica 8: 69-77.

GYÖRKE MAGDOLNA 1991. A kárpátaljai magyar szaknyelvek. In: GYÖRI-NAGY SÁNDORKelEMEN JANKA szerk., Kétnyelvüség a Kárpát-medencében. Budapest, Széchenyi társaság-Pszicholingva Nyelviskola. 70-71.

Hoffmann OtTó 1996. Mini-tini-szótár. Pécs, Janus Pannonius Tudományegyetem Kiadója.

HUSZTI ILONA 2017. Hogyan hat a kárpátaljai magyar iskolák angoltanárainak nyelvtudásszintje a nyelvtanítás folyamatára? Közoktatás. A Kárpátaljai Magyar Pedagógusszövetség lapja 22/4: 16-17.

KISS ANITA 2020. The use of Hungarian language and language attitude in the Subcarpathian region amongst university and college students. Argumentum 16: 1-13. 
LAKATOS KATALIN 2011. Kárpátaljai magyar iskolások nyelvi tudata és attitüdje. Doktori értekezés. Kézirat. Budapest, Eötvös Loránd Tudományegyetem, Bölcsészettudományi Kar. URL: http://doktori.btk.elte.hu/lingv/lakatoskatalin/diss.pdf (2021. 01. 04.)

MÁRKU ANITA 2008. Szókölcsönzés a kárpátaljai magyar főiskolások és egyetemisták körében. Alkalmazott Nyelvtudomány 8: 27-39.

MÁTÉ RÉKA 2017. Angol és ukrán nyelvi felmérések tapasztalatai Kárpátalja magyar tannyelvü általános iskoláiban. Közoktatás. A Kárpátaljai Magyar Pedagógusszövetség lapja 22/4: 14-15.

NAGY NATÁLIA 2020. A szórványban élő iskolások nyelvhasználatának sajátosságai egy kérdöíves kutatás alapján. Acta Universitatis de Carolo Eszterházy Nominatae: Sectio Linguistica Hungarica 46: 129-142.

PARAPATICS ANDREA 2013. Fiatalok nyelvi mentalitása és a szleng. Doktori értekezés. Kézirat. Budapest, Eötvös Loránd Tudományegyetem, Bölcsészettudományi Kar. URL: http://doktori.btk.elte.hu/lingv/parapaticsandrea/diss.pdf (2021. 01. 04.)

SÉRA MAGDOLNA 2009. Az iskolai tannyelvválasztás szerepe a kárpátaljai magyar kisebbség jövője és társadalmi mobilitása szempontjából. In: KÖTÉL EMŐKE-SZARKA LÁSZLÓ szerk., Határhelyzetek 2. Kultúra-Oktatás-Nyelv-Politika. Budapest, Balassi Intézet Márton Áron Szakkollégium. 241-268.

SzÜTS LÁSZLÓ 1994. A diákok nyelvéröl. Honismeret 22/3: 51-54.

\section{The influence of the state language on the language use of students studying in Hungarian higher education in Transcarpathia}

Until now, linguists dealing with student language use have not been able to clearly define what exactly the term student language means: the full usage of language by school-age young people, or the use of language related to school life, including the names of educational units, subjects, teaching aids and grades. However, they overwhelmingly agree that relatively identical attributes characterize students' language use within the borders of the country.

The state languages of the individual countries have an increased influence on the Hungarian language outside Hungary's borders, and this influence affects the students' language as well. Research on this subject has consistently shown that students' language use is not free from contact effects either.

Within the framework of the present paper, based on the results of sociolinguistic research, I try to examine the extent to which the effect of the state language appears in the student language in the narrower sense, among students studying in Hungarian higher education in Transcarpathia.

Keywords: Transcarpathia, Hungarian language, state language, loan elements, student language, higher education

Gazdag Vilmos

ORCID: 0000-0002-9331-2307

II. Rákóczi Ferenc Kárpátaljai Magyar Főiskola, Beregszász gazdagvilmos@gmail.com 
